\title{
Agronomic Performance and Heterosis in Common Bean Genotypes
}

\author{
Valvenarg Pereira da Silva, Marco Antonio Aparecido Barelli, Rafhael Felipin-Azevedo \\ State University of Mato Grosso - Brazil
}

Juliana Parisotto Poletine

State University of Maringá - Brazil

Cristiani Santos Bernini

State University of Mato Grosso - Brazil

Received: July 7, 2020

Accepted: Sep. 14, $2020 \quad$ Published: Sep. 15, 2020

doi:10.5296/jas.v8i4.17329

URL: https://doi.org/10.5296/jas.v8i4.17329

\begin{abstract}
The agronomic performance and heterosis of common bean genotypes were evaluated using the diallel cross between two cultivars IPR Uirapuru and IPR Campos Gerais and five local varieties BGU-1, BGU-7, BGU-13, BGU-36 and BGU-36 and its 21 possible diallel hybrids. The treatments were evaluated under greenhouse conditions in a randomized block design with ten replications, at the Empresa Mato-Grossense de Pesquisa, Assistência e Extensão Rural (EMPAER), in the county of Cáceres, state of Mato Grosso, Brazil. The characteristics were evaluated: average number of days for emergence, number of days for flowering, average height of insertion of the first pod, average final height of plants, average stem diameter, average longitudinal length of pods, average total number of pods per plant, average number of seeds per pod, average number of seeds per plant, average weight of seeds and grain production. Based on the set of analysis performed and the characteristics evaluated, it can be concluded that for the increase in production the combinations composed by the parents IPR Uirapuru $\times$ BGU-1, IPR Uirapuru $\times$ BGU-6, BGU-7 $\times$ BGU-1, BGU $-7 \times$ BGU-36, BGU-1 $\times$ BGU-36, BGU-25 x BGU-36 and BGU-13 $\times$ BGU-36 showed positive heterotic magnitudes being the most promising to provide highly productive lines.
\end{abstract}

Keywords: Phaseolus vulgaris L., plant breeding, agronomic characteristics 


\section{Introduction}

Worldwide, common beans (Phaseolus vulgaris L.) are the most important legume in terms of food, due to their grain being a rich source of essential proteins and amino acids (Talukder et al., 2010; Kalavacharla et al., 2011). It is widely cultivated in different parts of the world as well as in Brazil where it is produced in practically all regions of the country, using different technological levels in the production systems (Baldissera et al., 2012).

Common beans have high genetic diversity, however in Brazil as in the world, genetic variability is tending to extinction, due to the intense cultivation of single cultivars, or those from a few parents (Tsutsumi et al., 2015). Bitocchi et al. (2013) points out those bean cultivars of Mesoamerican origin suffered a severe reduction in genetic diversity, showing loss of $72 \%$ of diversity during the domestication process.

The expansion of genetic diversity via hybridizations between contrasting superior parents for the characters of interest is widely used in breeding programs, since these hybridizations aim to combine desirable allele progenies that were in different parents (Zimmermann et al., 1996; Rocha et al., 2014).

Information about the behavior of progenies is obtained by diagnosing the results that can be performed by average of diallel analyzes that aim to estimate the general and specific combining ability by the Griffing model (1956), to estimate the values of average, varietal heterosis and specific by the method of Gardner \& Eberhanrt (1966) and provides information on genetic control by the method of Jinks \& Hayman (1953) (Cruz, 2006).

In addition to the analyzes mentioned above, Kurek et al. (2001) and Silva (2013), demonstrate that the use of the original average values of the evaluated characteristics facilitates the verification of the best parents in advance of the diallel analysis, demonstrating the agronomic variability and potential that exists between the evaluated genotypes and hybrids. Several researchers Atnaf et al. (2014), Rocha et al. (2014), Senbetay \& Tesfaye (2015) and Vale et al. (2015), studied the averages previously and/or used it as an addition to the results of the diallel analyzes.

The evaluation of the agronomic performance of progenies and heterosis, which is defined as the genetic manifestation of the beneficial effects of hybridizations (Vieira, 1964; Falconer, 1987), has been analyzed among bean breeders in order to verify the increase in the desired characteristics (Barelli et al., 1998; Torres et al., 2002; Vidigal et al., 2008; Tiruneh et al., 2013; Ceyhan et al., 2014).

Vieira (1964), points out that the heterosis in beans can manifest itself in several ways, by the increase in the number of pods per plant, in the height of plants, in the number of grains, among others. In this context, the present research aims to evaluate the agronomic performance and the heterotic gain of parents and their respective common bean hybrids.

\section{Material and Methods}

Seven common bean genotypes, five local varieties BGU-7, BGU-1, BGU-13, BGU-25 and BGU-36 from the Active Germplasm Bank (BAG) from Phaseolus vulgaris from the State 
University of Mato Grosso, campus of Cáceres and two commercial cultivars IPR Uirapuru and IPR Campos Gerais both from the Agronomic Institute of Paraná (IAPAR), were used for the production of hybrids in a complete dialect scheme, without reciprocal. In the hybridization process, the emasculation methodology of the floral button with interlacing was used (Peternelli \& Borém 1999). The crossings were carried out in a greenhouse in the morning (07:00 to 10:00 h) and afternoon (15:00 to 18:00 h), in which the temperature during the hybridizations varied from $20^{\circ} \mathrm{C}$ to $34{ }^{\circ} \mathrm{C}$.

The 21 hybrids together with the seven parents were evaluated from February to April 2017, in a greenhouse condition in the Empresa Mato-Grossense de Pesquisa, Assistência e Extensão Rural (EMPAER), in the county of Cáceres-MT, $\left(16^{\circ} 43^{\prime} 42^{\prime \prime}\right.$ South and longitude $\left.57^{\circ} 40^{\prime} 51^{\prime \prime}\right)$. The characteristic climate of the region, according to the Köppen classification, is of the tropical, hot, humid and dry winter (Awa) type, with rainy periods varying from October to March, and drought from April to September (Dallacort et al., 2014).

The cultivation of the parents and their hybrids were carried out in plastic pots, with a capacity of $5.0 \mathrm{~L}$. The substrate used was the commercial Topstrato HT®, prior to planting, mineral fertilization was performed, consisting of $20 \mathrm{~g}$ of $\mathrm{N}, \mathrm{P}_{2} \mathrm{O}_{5}$ and $\mathrm{K} 2 \mathrm{O}$ 4-14-8 per pot. After 15 days, fertilization started, with weekly application of nitrogen at a dosage of 50 $\mathrm{mg} / \mathrm{dm}^{3}$ in coverage, using ammonium sulfate $\left[\left(\mathrm{NH}_{4}\right)_{2} \mathrm{SO}_{4}\right]$ as the source. When flowering occurred, potassium chloride $(\mathrm{KCl})$ was also applied, at a dosage of $75 \mathrm{mg} / \mathrm{dm}^{3}$, weekly, together with nitrogen. Four seeds were used per pot, seven days after emergence, thinning was performed, leaving two plants per pot.

The design used was randomized blocks, with 28 treatments and ten repetitions, in which the experimental unit was composed of a pot with two bean plants. The following characteristics were evaluated: average number of days for emergence (EMERG), number of days for flowering (FLOWER), average height of insertion of the first pod (INSERT) expressed in centimeters average final height of plants (HEIGHT) expressed in meters, average stem diameter (SD), average longitudinal pod length (LL), average total number of pods per plant (PP), average number of seeds per pod (SPOD), average number of seeds per plant (SPLANT), average seed weight (WEIGHT50) expressed in grams grain production (PROD) expressed in grams/plants.

The experimental data were submitted to analysis of variance and, when significant by the $\mathrm{F}$ test, the averages were grouped by the Scott-Knott test at $1 \%$ probability of error. The average percentage heterosis, for each evaluated trait, was obtained in relation to the average of the parents, through the following expression:

$$
H m p(\%)=\left[\bar{Y}_{i j}-\left(\frac{\bar{Y}_{i i}+\bar{Y}_{j j}}{2}\right)\right] \times 100
$$

Hmp (\%)is the average percentage heterosis;

$\bar{Y} \mathrm{ij}, \quad \bar{Y}$ ii e $\bar{Y} \mathrm{jj}$ are the respective averages of the combination $\mathrm{ij}$ and the parents $\mathrm{i}$ and $\mathrm{j}$. 
All statistical analyzes were performed with the aid of the computer program Genes version 2016.6.0 (Cruz, 2013).

\section{Results and Discussion}

For all characteristics evaluated, significant differences were recorded at the level of $1 \%$ probability (Table 1), showing the existence of genetic diversity among the parents used in the diallel crosses, which allows genetic gains in the bean breeding program using these parents. The existence of this genetic variability in the genotypes used as parents, is of fundamental importance for works of this nature, as emphasized by Krause et al. (2012), Rocha et al. (2014) and Leite et al. (2019).

The coefficients of experimental variation $(\mathrm{CV})$, shown in table 1 , were low to medium in magnitude, as pointed out by Pimentel Gomes (2009), indicating good experimental precision, considering that the CV was less than 20\%. Except for the characteristics Height of insertion of the first pod, total number of pods per plant, average number of seeds per plant and average grain production, which reached $\mathrm{CV}$ of $31.66,26.23,27.16$ and $32.27 \%$, these higher $\mathrm{CV}$ results for these characters in bean culture are expected, since characters linked to production and controlled by several genes tend to be influenced by the environment. High CV values in the bean culture for characters linked to production have been previously reported by Baldissera et al. (2014), Rocha et al. (2014), Gerrano et al. (2015) and Correa et al. (2015).

The analysis of grouping of average of the parents and hybrids in relation to the evaluated characters were performed by the Scott-Knott's test. The use of averages facilitates the verification of the best parents and demonstrates the agronomic potential of their respective hybrids. For the characteristic of emergence and flowering, the objectives are similar in that individuals with lower average values are sought, that is, individuals who have a shorter seedling emergence period and also shorter flowering times, thus combining $3 \times 4,3 \times 6,4 \times 7$ and $5 \times 6$ stood out in both characteristics presenting values of 3.80, 3.35, 3.45 and 3.37 days for emergency and 33.20, 33.20, 33.60 and 33.60 days to flowering, respectively (Table 2).

Table 1. Summary of the analysis of variance for 11 evaluated agronomic characteristics, parents and respective hybrid combinations, resulting from the diallel crosses between seven genotypes (two cultivars and five local varieties) of Phaseolus vulgaris L. Cáceres-Mato Grosso

\begin{tabular}{|c|c|c|c|c|c|c|c|c|c|c|c|c|}
\hline \multirow[b]{2}{*}{$F V$} & \multicolumn{12}{|c|}{ Mean square ${ }^{\prime I}$} \\
\hline & $G L$ & EMERG & FLOWER & INSERT & HEIGHT & $S D$ & $L L$ & $P P$ & SPOD & SPLANT & WEIGHT50 & PROD \\
\hline Blocks & 9 & 0.6487 & 4.7286 & 133.7151 & 0.2165 & 1.7538 & 0.0938 & 49.7509 & 0.3218 & 1254.8521 & 8.4873 & 58.2458 \\
\hline Genotypes & 27 & $3.5777 * *$ & $28.6032 * *$ & $1247.6618^{* * *}$ & $3.3765^{* * *}$ & $2.8238 * *$ & $2.9373 * *$ & $107.9482 * *$ & $3.5976 * *$ & $3949.1583 * *$ & $30.1585 * *$ & $88.5817 * *$ \\
\hline Error & 243 & 0.4487 & 2.0850 & 145.9691 & 0.1163 & 0.2814 & 0.1946 & 31.3799 & 0.7787 & 685.0527 & 5.4728 & 28.4131 \\
\hline Average & - & 4.36 & 35.54 & 38.17 & 1.98 & 5.52 & 10.38 & 21.36 & 4.56 & 96.37 & 27.48 & 16.52 \\
\hline$C V(\%)$ & - & 15.35 & 4.06 & 31.66 & 16.25 & 9.62 & 4.25 & 26.23 & 19.35 & 27.16 & 8.51 & 32.27 \\
\hline
\end{tabular}

${ }^{1 /}$ EMERG = average number of days for emergence; FLOWER = number of days to flower; INSERT = average height of insertion of the first pod; HEIGHT = final plant height; SD = average stem diameter; $\mathrm{LL}=$ average longitudinal length of pods; $\mathrm{PP}=$ average total number of pods per plant; SPOD = average number of seeds per plant; SPLANT = average number of seeds per pod; WEIGHT50 = average weight of 50 seeds and PROD = average grain production. $* *$ significant at the $1 \%$ probability level, by the $\mathrm{F}$ test. 
Table 2. Averages values of the parents and respective F1's hybrids for 11 agronomic characteristics evaluated in hybrid combinations and their parents, resulting from the diallel crosses between seven genotypes (two cultivars and five local varieties) of Phaseolus vulgaris $\mathrm{L}$

\begin{tabular}{|c|c|c|c|c|c|c|c|c|c|c|c|}
\hline \multirow{2}{*}{$\begin{array}{l}\text { Parents/hybrid } \\
\text { combinations }\end{array}$} & \multicolumn{11}{|c|}{ Agronomic characteristics ${ }^{1 /}$} \\
\hline & EMERG & FLOWER & INSERT & HEIGHT & $S D$ & $L L$ & $P P$ & SPOD & SPLANT & $\begin{array}{c}\text { WEIGHT5 } \\
0\end{array}$ & PROD \\
\hline IPR Uirapuru (1) & $4.15 \mathrm{c}^{2 /}$ & $38.20 \mathrm{a}$ & $34.30 \mathrm{c}$ & $1.87 \mathrm{~b}$ & $6.19 \mathrm{~b}$ & $10.06 \mathrm{c}$ & $18.20 \mathrm{c}$ & $5.26 \mathrm{a}$ & $95.75 \mathrm{c}$ & $25.91 \mathrm{~b}$ & $12,95 \mathrm{~b}$ \\
\hline BGU-7 (2) & $4.30 \mathrm{c}$ & $37.40 \mathrm{~b}$ & $28.50 \mathrm{~d}$ & $2.26 \mathrm{~b}$ & $6.36 \mathrm{~b}$ & $9.72 \mathrm{c}$ & $20.70 \mathrm{c}$ & $4.88 \mathrm{a}$ & $100.10 \mathrm{c}$ & $24.40 \mathrm{c}$ & $12,20 \mathrm{~b}$ \\
\hline BGU-1 (3) & $5.53 \mathrm{a}$ & $35.00 \mathrm{c}$ & $25.45 \mathrm{~d}$ & $0.91 \mathrm{c}$ & $5.11 \mathrm{~d}$ & $11.15 \mathrm{a}$ & $18.25 \mathrm{c}$ & $3.88 \mathrm{~b}$ & $70.60 \mathrm{c}$ & $27.60 \mathrm{~b}$ & $13,80 \mathrm{~b}$ \\
\hline BGU-25 (4) & $4.90 \mathrm{~b}$ & $34.90 \mathrm{c}$ & $26.35 \mathrm{~d}$ & $0.95 \mathrm{c}$ & $5.39 \mathrm{c}$ & $9.92 \mathrm{c}$ & $18.05 \mathrm{c}$ & $4.41 \mathrm{~b}$ & $79.80 \mathrm{c}$ & $27.04 \mathrm{~b}$ & $13,52 \mathrm{~b}$ \\
\hline BGU-13 (5) & $4.58 \mathrm{~b}$ & $33.50 \mathrm{~d}$ & $22.45 \mathrm{~d}$ & $0.72 \mathrm{c}$ & $5.87 \mathrm{~d}$ & $9.63 \mathrm{c}$ & $18.10 \mathrm{c}$ & $4.38 \mathrm{~b}$ & $78.35 \mathrm{c}$ & $23.34 \mathrm{c}$ & $11,67 \mathrm{~b}$ \\
\hline BGU-36 (6) & $5.55 \mathrm{a}$ & $38.40 \mathrm{a}$ & $54.80 \mathrm{a}$ & $2.27 \mathrm{~b}$ & $5.03 \mathrm{~d}$ & $9.47 \mathrm{c}$ & $22.85 \mathrm{c}$ & $3.41 \mathrm{~b}$ & $76.70 \mathrm{c}$ & $28.63 \mathrm{a}$ & $14,31 \mathrm{~b}$ \\
\hline IPR Campos gerais (7) & $4.27 \mathrm{c}$ & $37.40 \mathrm{~b}$ & $44.35 \mathrm{~b}$ & $2.20 \mathrm{~b}$ & $5.79 \mathrm{~b}$ & $10.38 \mathrm{~b}$ & $21.15 \mathrm{c}$ & $4.07 \mathrm{~b}$ & $84.75 \mathrm{c}$ & $28.94 \mathrm{a}$ & $14,47 \mathrm{~b}$ \\
\hline $1 \times 2$ & $4.00 \mathrm{c}$ & $38.10 \mathrm{a}$ & $34.25 \mathrm{c}$ & $2.29 \mathrm{~b}$ & $7.31 \mathrm{a}$ & $10.32 \mathrm{~b}$ & $31.30 \mathrm{a}$ & $5.11 \mathrm{a}$ & $155.20 \mathrm{a}$ & $25.95 \mathrm{~b}$ & $22,29 \mathrm{a}$ \\
\hline $1 \times 3$ & $4.90 \mathrm{~b}$ & $38.50 \mathrm{a}$ & $29.10 \mathrm{~d}$ & $2.15 \mathrm{~b}$ & $5.83 \mathrm{~b}$ & $11.38 \mathrm{a}$ & $25.35 \mathrm{~b}$ & $5.56 \mathrm{a}$ & $114.50 \mathrm{~b}$ & $29.76 \mathrm{a}$ & 20,89 a \\
\hline $1 \times 4$ & $4.67 \mathrm{~b}$ & $35.90 \mathrm{c}$ & $36.50 \mathrm{c}$ & $2.20 \mathrm{~b}$ & $5.42 \mathrm{c}$ & $10.31 \mathrm{~b}$ & $21.35 \mathrm{c}$ & $4.98 \mathrm{a}$ & $114.95 \mathrm{~b}$ & $27.03 \mathrm{~b}$ & $16,13 \mathrm{~b}$ \\
\hline $1 \times 5$ & $4.73 \mathrm{~b}$ & $36.90 \mathrm{~b}$ & $38.15 \mathrm{c}$ & $2.12 \mathrm{~b}$ & $6.16 \mathrm{~b}$ & $10.48 \mathrm{~b}$ & $21.50 \mathrm{c}$ & $5.23 \mathrm{a}$ & $112.55 \mathrm{~b}$ & $27.58 \mathrm{~b}$ & $17,99 \mathrm{a}$ \\
\hline $1 \times 6$ & $4.22 \mathrm{c}$ & $35.20 \mathrm{c}$ & $58.80 \mathrm{a}$ & $2.56 \mathrm{a}$ & $5.27 \mathrm{c}$ & $10.28 \mathrm{~b}$ & $19.85 \mathrm{c}$ & $3.80 \mathrm{~b}$ & $74.10 \mathrm{c}$ & $29.48 \mathrm{a}$ & $17,64 \mathrm{a}$ \\
\hline $1 \times 7$ & $4.05 \mathrm{c}$ & $37.10 \mathrm{~b}$ & $47.05 \mathrm{~b}$ & $2.25 \mathrm{~b}$ & $5.87 \mathrm{~b}$ & $10.50 \mathrm{~b}$ & $22.50 \mathrm{c}$ & $5.05 \mathrm{a}$ & $120.75 \mathrm{~b}$ & $27.03 \mathrm{~b}$ & $16,17 \mathrm{~b}$ \\
\hline $2 \times 3$ & $4.72 \mathrm{~b}$ & $35.60 \mathrm{c}$ & $28.70 \mathrm{~d}$ & $2.18 \mathrm{~b}$ & $5.50 \mathrm{c}$ & $11.04 \mathrm{a}$ & $24.70 \mathrm{~b}$ & $4.47 \mathrm{a}$ & $115.55 \mathrm{~b}$ & $28.23 \mathrm{a}$ & $18,29 \mathrm{a}$ \\
\hline $2 \times 4$ & $4.20 \mathrm{c}$ & $35.40 \mathrm{c}$ & $34.60 \mathrm{c}$ & $2.32 \mathrm{~b}$ & $5.62 \mathrm{c}$ & $10.32 \mathrm{~b}$ & $21.85 \mathrm{c}$ & $4.84 \mathrm{a}$ & $108.40 \mathrm{~b}$ & $26.41 \mathrm{~b}$ & $15,81 \mathrm{~b}$ \\
\hline $2 \times 5$ & $5.28 \mathrm{a}$ & $36.50 \mathrm{~b}$ & $30.90 \mathrm{~d}$ & $2.08 \mathrm{~b}$ & $5.49 \mathrm{c}$ & $9.99 \mathrm{c}$ & $22.55 \mathrm{c}$ & $4.68 \mathrm{a}$ & $108.50 \mathrm{~b}$ & $26.27 \mathrm{~b}$ & $14,33 \mathrm{~b}$ \\
\hline $2 \times 6$ & $4.25 \mathrm{c}$ & $35.60 \mathrm{c}$ & 57.73 a & $2.75 \mathrm{a}$ & $5.27 \mathrm{c}$ & $9.80 \mathrm{c}$ & $19.30 \mathrm{c}$ & $3.78 \mathrm{~b}$ & $75.10 \mathrm{c}$ & $30.74 \mathrm{a}$ & $18,80 \mathrm{a}$ \\
\hline $2 \times 7$ & $3.60 \mathrm{~d}$ & $35.10 \mathrm{c}$ & $39.75 \mathrm{c}$ & $2.10 \mathrm{~b}$ & $6.08 \mathrm{~b}$ & $10.32 \mathrm{~b}$ & $21.95 \mathrm{c}$ & $4.91 \mathrm{a}$ & $106.30 \mathrm{~b}$ & $25.86 \mathrm{~b}$ & $15,77 \mathrm{~b}$ \\
\hline $3 \times 4$ & $3.80 \mathrm{~d}$ & $33.20 \mathrm{~d}$ & $29.00 \mathrm{~d}$ & $1.11 \mathrm{c}$ & $4.98 \mathrm{~d}$ & $11.32 \mathrm{a}$ & $17.25 \mathrm{c}$ & $4.91 \mathrm{a}$ & $85.25 \mathrm{c}$ & $27.23 \mathrm{~b}$ & $14,93 \mathrm{~b}$ \\
\hline $3 \times 5$ & $4.70 \mathrm{~b}$ & $34.20 \mathrm{~d}$ & $23.90 \mathrm{~d}$ & $0.83 \mathrm{c}$ & $4.88 \mathrm{~d}$ & $10.78 \mathrm{a}$ & $18.55 \mathrm{c}$ & $5.43 \mathrm{a}$ & $73.00 \mathrm{c}$ & $26.02 \mathrm{~b}$ & $13,01 \mathrm{~b}$ \\
\hline $3 \times 6$ & $3.35 \mathrm{~d}$ & $33.20 \mathrm{~d}$ & $44.05 \mathrm{~b}$ & $2.20 \mathrm{~b}$ & $4.89 \mathrm{~d}$ & $11.04 \mathrm{a}$ & $20.70 \mathrm{c}$ & $3.56 \mathrm{~b}$ & $91.75 \mathrm{c}$ & $28.46 \mathrm{a}$ & $20,04 \mathrm{a}$ \\
\hline $3 \times 7$ & $4.38 \mathrm{c}$ & $34.80 \mathrm{c}$ & $47.30 \mathrm{~b}$ & $2.28 \mathrm{~b}$ & $4.95 \mathrm{~d}$ & $11.39 \mathrm{a}$ & $19.15 \mathrm{c}$ & $4.98 \mathrm{a}$ & $95.00 \mathrm{c}$ & $28.28 \mathrm{a}$ & $14,14 \mathrm{~b}$ \\
\hline $4 \times 5$ & $5.00 \mathrm{~b}$ & $34.90 \mathrm{c}$ & $22.75 \mathrm{~d}$ & $1.03 \mathrm{c}$ & $6.72 \mathrm{a}$ & $9.92 \mathrm{c}$ & $30.00 \mathrm{a}$ & $4.23 \mathrm{~b}$ & $125.90 \mathrm{~b}$ & $25.75 \mathrm{~b}$ & $21,76 \mathrm{a}$ \\
\hline $4 \times 6$ & $3.87 \mathrm{c}$ & $32.80 \mathrm{~d}$ & $36.27 \mathrm{c}$ & $2.34 \mathrm{~b}$ & $5.26 \mathrm{c}$ & $10.17 \mathrm{~b}$ & $19.45 \mathrm{c}$ & $4.79 \mathrm{a}$ & $82.45 \mathrm{c}$ & $28.91 \mathrm{a}$ & $17,25 \mathrm{a}$ \\
\hline $4 \times 7$ & $3.45 \mathrm{~d}$ & $33.60 \mathrm{~d}$ & $42.05 \mathrm{~b}$ & $2.33 \mathrm{~b}$ & $5.06 \mathrm{~d}$ & $10.35 \mathrm{~b}$ & $20.40 \mathrm{c}$ & $4.51 \mathrm{a}$ & $92.20 \mathrm{c}$ & $29.80 \mathrm{a}$ & $16,46 \mathrm{~b}$ \\
\hline $5 \times 6$ & $3.37 \mathrm{~d}$ & $33.60 \mathrm{~d}$ & $49.70 \mathrm{~b}$ & $2.44 \mathrm{a}$ & $4.89 \mathrm{~d}$ & $9.70 \mathrm{c}$ & $22.00 \mathrm{c}$ & $3.57 \mathrm{~b}$ & $79.10 \mathrm{c}$ & $29.89 \mathrm{a}$ & $20,90 \mathrm{a}$ \\
\hline $5 \times 7$ & $4.42 \mathrm{c}$ & $34.90 \mathrm{c}$ & $42.90 \mathrm{~b}$ & $2.15 \mathrm{~b}$ & $5.03 \mathrm{~d}$ & $10.46 \mathrm{~b}$ & $19.95 \mathrm{c}$ & $4.79 \mathrm{a}$ & $94.90 \mathrm{c}$ & $27.29 \mathrm{~b}$ & $19,13 \mathrm{a}$ \\
\hline $6 \times 7$ & $3.90 \mathrm{c}$ & $35.30 \mathrm{c}$ & $59.00 \mathrm{a}$ & $2.30 \mathrm{~b}$ & $5.11 \mathrm{~d}$ & $10.37 \mathrm{~b}$ & $21.10 \mathrm{c}$ & $4.11 \mathrm{~b}$ & $86.95 \mathrm{c}$ & $27.46 \mathrm{~b}$ & $17,77 \mathrm{a}$ \\
\hline
\end{tabular}

${ }^{1 /}$ EMERG = average number of days for emergence; FLOWER = number of days to flower; INSERT $=$ average height of insertion of the first pod; HEIGHT $=$ final plant height; SD = average stem diameter; $\mathrm{LL}=$ average longitudinal length of pods; $\mathrm{PP}=$ average total number of pods per plant; SPOD = average number of seeds per plant; SPLANT $=$ average number of seeds per pod; WEIGHT50 = average weight of 50 seeds and PROD $=$ average grain production . ${ }^{2 /}$ Averages followed by the same letter do not differ by the Scott-Knott test, at the level of $1 \%$.

These average values presented in the present research for the flowering characteristic are better when compared with 11 common bean cultivars from the early group evaluated by Leite et al. (2015) whose flowering values were 38.66 to 44.33 days as well as the result of the hybrid combinations of the research carried out by Atnaf et al. (2014) who obtained average values from 38.5 to 52.5 days. With this, the hybrid combinations $3 \times 4,3 \times 6,4 \times 7$ and $5 \times 6$ showed potentiality in the precocity question and can be explored in genetic improvement programs in obtaining superior segregating populations. 
Regarding the height of insertion of the first pod, the values of the parents and their respective combinations, the values will ranged from 22.45 to $59.00 \mathrm{~cm}$ (Table 2), these values are satisfactory since values above $15 \mathrm{~cm}$ facilitate production in large scale facilitating mechanized harvesting and providing less grain losses, since it avoids direct contact of pods with soil as pointed out by Oliveira et al. (2014).

About the plant height Gonçalves (1979) points out that cultivars that exhibit greater plant height are highly desired, since the plant height is related to grain yield, thus the hybrid combinations $1 \times 6,2 \times 6$ and $5 \times 6$, made up the group with the highest averages with 2.56, 2.75 and $2.44 \mathrm{~cm}$, respectively (Table 2 ), being those indicated for breeding programs that aim to increase these characteristics.

Regarding the stem diameter, genotypes are separated into four groups, with values ranging from 7.31 to $4.88 \mathrm{~cm}$ (Table 2). According to Coelho et al. (2007) this characteristic is not very relevant in research that analyzes genetic divergence and in the identification of duplicity in germplasm collections. However, the stem diameter plays an important role in supporting the plant, so that larger diameters prevent lodging, facilitating the mechanization process as pointed out by Oliveira et al. (2014). In this sense, the values obtained in this research are adequate for good plant support in the soil and ease for mechanized harvesting.

For medium longitudinal length of the pods, three groups were formed, with the highest averages ranging from 10.78 to $11.39 \mathrm{~cm}$. Regarding the total number of pods per plant, the formation of three groups can be observed (Table 2). With the superior results being obtained by hybrid combinations $1 \times 2$ and $4 \times 5$ with an average of 31.30 and 30.00 pods per plant, respectively. These results are similar to the hybrid bean combinations of the research carried out by Arunga et al. (2010) in which the pod average per plant varied from 16.64 to 32.40 and higher than the results obtained by Stähelin et al. (2011), in research evaluating the genetic diversity of 38 accessions and 2 commercial cultivars IPR Uirapuru and BRS Supremo, with an average number of pods per plant ranging from 6.7 to 21.3.

The hybrid combinations and the parents were grouped into two groups for the average number of seeds per pod, with the group consisting of the hybrid combinations $1 \times 2,1 \times 3,1$ $\times 4,1 \times 5,1 \times 7,2 \times 3,2 \times 4,2 \times 5,2 \times 7,3 \times 4,3 \times 5,3 \times 7,4 \times 6,4 \times 7,5 \times 7$ and the parents IPR Uirapuru (1) and BGU-7 (2), stood out with an average of seeds per pod from 4.88 to 5.56 (Table 2). These results are similar to the hybrid combinations of the research Kurek et al (2001), in which these authors evaluated the hybrid combinations of the cultivars Rudá, Pérola and CI 9661 of the group from Rio, and CI 967/2V, IAPAR 44 and FT Nobre of the group of black beans that presented values from 4.70 to 5.60 .

The hybrid combination composed by the parents IPR Uirapuru (1) and BGU-7 (2), obtained the best result for the average number of seeds per plant, with an average of 155.20 (Table 2). Followed by the hybrid combinations composed by the parents $1 \times 3,1 \times 4,1 \times 5,1 \times 7,2 \times$ $3,2 \times 4,2 \times 5,2 \times 7$ and $4 \times 5$ also stood out, presenting superior results in their parents. Such results are relevant to the genetic improvement program, considering that several hybrid combinations were superior to the parents, this demonstrates the beneficial effects of hybridization as previously reported by Santos et al. (2011). 
For the average weight of 50 seeds, the parents and their respective hybrids were grouped into 3 groups, the group that showed superiority showed average values of 28.23 to $30.74 \mathrm{~g}$, being composed by the parents BGU-36 (6) and IPR Campos Gerais (7) and hybrid combinations $1 \times 3,1 \times 6,2 \times 3,2 \times 6,3 \times 6,3 \times 7,4 \times 6,4 \times 7$ and $5 \times 6$. These results were satisfactory for the bean culture and the hybrid combinations of the LPSPI 93-17, LPSPI 93-19, FT-Nobre, Aporé, Rudá and Campeão-1 parents were also superior in the research carried out by Barelli (1997) in which the best hybrid combination obtained $15.20 \mathrm{~g}$.

Comparing the estimates of grain production averages, the Scott-Knott cluster analysis shows the formation of two groups, the one with the best result being composed exclusively by the following hybrid combinations: $1 \times 2,1 \times 3,1 \times 5,1 \times 6,2 \times 3,2 \times 6,3 \times 6,4 \times 5,4 \times 6,5 \times$ $6,5 \times 7$ and $6 \times 7$ in which they obtained values from 17,25 to $22,29 \mathrm{~g} /$ plant (Table 2).

In the evaluation of the average percentage heterosis, the hybrid combinations expressed negative and positive values. According to Barelli et al. (1998) the results for each trait must be carefully analyzed, according to what is really desired in each genetic improvement program, bearing in mind that, for some characteristics, negative values are preferred to positive ones. As for the emergence feature, which actually aims, how much comes in seedling emergency period is negative heterosis for portraying smaller planting time intervals to the emergence of seedlings. In this way, it can be said that the best hybrid combinations for these characteristics were $3 \times 6,5 \times 6$ with percentage values of heterosis of -39.54 and $-33.38 \%$ respectively (Table 3 ). Note that these combinations expressed the lowest averages for the number of emergency days, whose respective average values were 3.35 and 3.37 days (Table 2).

Table 3. Heterosis estimates of the 21 hybrid common bean combinations, based on parents' averages values (HMP)

\begin{tabular}{|c|c|c|c|c|c|c|c|c|c|c|c|}
\hline \multirow{2}{*}{$\begin{array}{c}\text { Hybrid } \\
\text { combinations }\end{array}$} & \multicolumn{11}{|c|}{ Average percentage heterosis } \\
\hline & ${ }^{1 / E M E R G ~}$ & FLOWER & INSERT & HEIGHT & $\mathrm{SD}$ & LL & $\mathrm{PP}$ & SPOD & SPLANT & WEIGHT50 & PROD \\
\hline $1 \times 2$ & -5.32 & 0.79 & 9.07 & 10.85 & 16.49 & 4.35 & 60.92 & 0.85 & 58.48 & 3.14 & 77.24 \\
\hline $1 \times 3$ & 1.21 & 5.19 & -2.59 & 55.32 & 3.10 & 7.29 & 39.09 & 21.59 & 37.66 & 11.21 & 56.15 \\
\hline $1 \times 4$ & 3.31 & -1.77 & 20.36 & 56.66 & -6.48 & 3.17 & 17.79 & 3.07 & 30.95 & 2.09 & 21.82 \\
\hline $1 \times 5$ & 8.39 & 2.92 & 34.44 & 63.74 & 11.39 & 6.38 & 18.45 & 8.44 & 29.29 & 12.00 & 46.09 \\
\hline $1 \times 6$ & -12.88 & -8.09 & 31.98 & 23.69 & -6.13 & 5.23 & -3.28 & -12.28 & -14.06 & 8.10 & 29.38 \\
\hline $1 \times 7$ & -3.85 & -1.85 & 19.64 & 10.78 & -2.09 & 2.76 & 14.35 & 8.22 & 33.79 & -1.42 & 17.93 \\
\hline $2 \times 3$ & -4.06 & -1.65 & 6.39 & 37.44 & -4.18 & 5.74 & 26.82 & 2.15 & 35.38 & 8.58 & 40.72 \\
\hline $2 \times 4$ & -8.52 & -2.07 & 26.16 & 44.38 & -4.32 & 5.04 & 12.77 & 4.25 & 20.51 & 2.67 & 22.98 \\
\hline $2 \times 5$ & 18.94 & 2.96 & 21.29 & 39.32 & -2.24 & 3.26 & 16.23 & 1.14 & 21.60 & 10.04 & 20.12 \\
\hline $2 \times 6$ & -13.70 & -6.06 & 38.60 & 21.39 & -7.59 & 2.11 & -11.36 & -8.79 & -15.04 & 15.96 & 41.79 \\
\hline $2 \times 7$ & -16.03 & -6.14 & 9.12 & -5.83 & 0.70 & 2.72 & 4.89 & 9.82 & 15.01 & -3.02 & 18.29 \\
\hline $3 \times 4$ & -27.14 & -5.00 & 11.96 & 19.78 & -5.15 & 7.46 & -4.95 & 18.37 & 13.36 & -0.33 & 9.28 \\
\hline $3 \times 5$ & -7.06 & -0.14 & -0.20 & 2.31 & -2.19 & 3.70 & 2.06 & 31.36 & -1.98 & 2.16 & 2.16 \\
\hline $3 \times 6$ & -39.54 & -9.53 & 9.78 & 38.41 & -3.56 & 7.03 & 0.72 & -2.30 & 24.57 & 1.21 & 42.58 \\
\hline $3 \times 7$ & -10.61 & -3.86 & 35.53 & 46.63 & -9.11 & 5.80 & -2.79 & 25.21 & 22.30 & 0.04 & 0.04 \\
\hline $4 \times 5$ & 5.45 & 2.04 & -6.76 & 23.83 & 30.93 & 1.48 & 65.97 & -3.78 & 59.21 & 2.22 & 72.77 \\
\hline $4 \times 6$ & -25.83 & -10.50 & -10.59 & 45.49 & 0.83 & 4.92 & -4.88 & 22.54 & 5.36 & 4.13 & 23.98 \\
\hline $4 \times 7$ & -24.79 & -7.05 & 18.96 & 47.62 & -9.56 & 2.01 & 4.08 & 6.39 & 12.06 & 6.44 & 17.59 \\
\hline $5 \times 6$ & -33.38 & -6.53 & 28.67 & 62.55 & -1.22 & 1.51 & 7.44 & -8.22 & 2.031 & 15.03 & 60.84 \\
\hline $5 \times 7$ & -0.09 & -1.55 & 28.44 & 46.79 & -5.68 & 4.59 & 1.65 & 13.35 & 16.37 & 4.41 & 46.37 \\
\hline $6 \times 7$ & -20.61 & -6.86 & 19.02 & 2.69 & -5.66 & 4.53 & -4.09 & 9.81 & 7.71 & 4.59 & 23.49 \\
\hline
\end{tabular}


${ }^{1 / E M E R G ~=~ a v e r a g e ~ n u m b e r ~ o f ~ d a y s ~ f o r ~ e m e r g e n c e ; ~ F L O W E R ~=~ n u m b e r ~ o f ~ d a y s ~ t o ~ f l o w e r ; ~}$ INSERT = average height of insertion of the first pod; HEIGHT = final plant height; SD = average stem diameter; $\mathrm{LL}=$ average longitudinal length of pods; $\mathrm{PP}=$ average total number of pods per plant; SPOD = average number of seeds per plant; SPLANT = average number of seeds per pod; WEIGHT50 = average weight of 50 seeds and PROD $=$ average grain production.

About the flowering, whose objective is similar to that intended for the emergence characteristic, the combinations between parents $4 \times 6,3 \times 6$ and $1 \times 6$ showed the highest negative magnitudes of heterosis of $-10.50,-9.53$ and $-8.09 \%$ respectively (Table 3 ). Of these, only the first two combinations are in the group with the lowest flowering days with average values of 32.80 and 33.30 days (Table 2). In this way, the hybrid combinations mentioned above have potentiality in the precocious question and can be explored in genetic improvement programs in obtaining superior segregating populations.

For the height of insertion of the first pod, the average heterosis ranged from -0.20 to $38.60 \%$, unlike the characteristics mentioned above, positive values are desirable, thus the combinations $2 \times 6,3 \times 7$ and $1 \times 5$ are stood out with positive magnitudes of $38.60,35.53$ and $34.44 \%$, respectively. It is noteworthy that hybrids with greater heterosis are not always synonymous with the elevation of the trait under study, since heterosis depends both on the amount of loci in heterozygosis and on the average of the parents (SILVA 2013; FARIA et al., 2012).

Referring to plant height characteristics, the $1 \times 5$ and $5 \times 6$ combinations obtained the highest magnitudes with values of 63.74 and $62.55 \%$ respectively (Table 3 ). These values are higher than those obtained by Barelli et al. (1998), whose most promising combinations were LPSPI 93-19 x Aporé, LPSPI 93-17 x Aporé and FT-Nobre x Aporé, with 41.05, 24.47 and $23.05 \%$, respectively.

Regarding the total number of pods per plant, the best results were obtained by combinations between parents $1 \times 2$ and $4 \times 5$ with heterosis of 60.92 and $65.97 \%$, respectively (Table 3 ). This characterizes that these combinations are extremely important, when the intention is to obtain bean plants that contain a greater number of plant pods. For the characteristic stem diameter, whose objective is to increase to avoid lodging the plants positive estimates of heterosis should be preferred, the highest magnitudes obtained by the combinations were 30.93 and $16.49 \%$, for the $4 \times 5$ and combinations $1 \times 2$, respectively (Table 3 ).

The highest magnitudes of average heterosis for the characteristic longitudinal average length of the pods were obtained by the hybrid combinations $3 \times 4,1 \times 3$ and $3 \times 6$, with respective values of 7.46, 7.29 and 7.03\% (Table 3). Similar results were obtained by Barelli et al. (1998), obtained with the highest heterotic magnitudes being expressed by the combinations between the genomes Aporé x Rudá (4.84\%), LPSPI 93-17 x Aporé (4.62\%) and LPSPI 93-19 x FT-Nobre (4,26\%).

The values of heterosis observed for total number of pods per plant ranged from -4.95 to $65.97 \%$, in which combinations between parents $4 \times 5$ and $1 \times 2$, should be preferred in breeding programs because they presented the highest positive magnitudes of 65.97 and 
$60.92 \%$, respectively, this fact represents that these combinations are more than $60 \%$ superior compared to the best parent of their combination. These values observed in this study are higher than those observed by Goncalves-Vidigal et al. (2008), evaluating the hybrid combinations generated by the parents BRSMG Talismã, IPR Uirapuru, FT Soberano, BRS Campeiro, IAC Tybatã and IPR Juriti.

The estimates of the effect of heterosis specify for the average number of seeds per pod show favorable effects to increase this characteristic through the crossings between the parents $4 \times$ 6 and $3 \times 5$, since they present a high percentage of heterosis of 22.54 and 31, 36, respectively (Table 13). These heterosis values $(\%)$ of the present research are similar to the results obtained by Torres et al. (2002), in the state of Durango-Mexico where the best combination for this characteristic was obtained by crossing Bayo victoria and Durango 222 with a heterosis value of $35.41 \%$. Goncalves-Vidigal et al. (2008), obtained higher values with the combination BRS Campeiro x IAC Tybatã with heterosis of $123.76 \%$.

The values of heterosis for the average number of seeds per plant varied from -15.04 to $59.21 \%$, and the combinations indicated for breeding programs for positive increase of this characteristic are $4 \times 5$ and $1 \times 2$ presenting a heterosis of 59, 21 and 58.48\%, respectively (Table 3). The values of these combinations are similar to the results obtained by Tiruneh et al. (2013), in a research carried out at the Agricultural Research Center Melkassa, in Ethiopia, for this characteristic with values of $57.88 \%$ for the combination between the parents of common beans Zebra $\times$ Red wolayta.

For the average weight of 50 seeds, except for the combinations $6 \times 7$ and $1 \times 7$, all the others obtained positive values for heterosis, presenting genetic gain in at least one of the parents of their combination. However, the combinations $4 \times 7,2 \times 6,1 \times 3$ and $5 \times 6$ stood out because they presented respective heterosis values of 6.44, 15.96, 11.21 and 15.03\% (Table 3).

The heterosis for average grain production was positive for all hybrid combinations, with the most promising combinations being composed by the following crossings between the parents $1 \times 2,4 \times 5$ and $5 \times 6$, with $77.24,72.77$ and 60,84\% respectively (Table 3 ). These combinations showed results superior to those obtained by Silva et al. (2013) evaluating 14 bean parents in partial diallel in Viçosa, Minas Gerais, in which their best combination for this trait was composed by the crossing between the A525 × L2 lines that showed a 55.99\% heterosis.

\section{Conclusion}

Based on the set of analysis performed and the characteristics evaluated, it can be concluded that:

For the precocity question, the combinations between the parents BGU-25 $\times$ BGU-36 and BGU-1 $\times$ BGU-36 stood out, being able to generate promising lines with shorter period of emergence and flowering of the plants.

To increase production, the combinations composed by the parents IPR Uirapuru $\times$ BGU-1, IPR Uirapuru × BGU-6, BGU-7 × BGU-1, BGU-7 × BGU-36, BGU-1 × BGU-36, BGU-25 x 
BGU-36 and BGU-13 $\times$ BGU-36 showed positive heterotic magnitudes being the most promising for providing highly productive lines.

\section{Acknowledgements}

The Mato Grosso State Research Support Foundation (FAPEMAT) for granting the scholarship.

\section{References}

Arunga, E. E., Van Rheenen, H. A., \& Owuoche, J. O. (2010). Diallel analysis of Snap bean (Phaseolus vulgaris L.) varieties for important traits. African Journal of Agricultural Research, 5(15), 1951-1957.

Atnaf, M., Tesfaye, K., Dagne, K., \& Mohammed., H. (2014). Hyman's diallel analysis to study genetic parameters of phenological traits common bean (Phaseolus vulgaris). International Journal of Agricultural Sciences and Natural Resources. 1(4), 65-71.

Baldissera, J. N. C., Valentini, G., Coan, M. M. D., Almeida, C. B., Guidolin, A. F., \& Coimbra, J. L. M. (2012). Capacidade combinatória e efeito recíproco em características agronômicas do feijão. Semina: Ciências Agrárias, 33(2), 471-480. https://doi.org/10.5433/1679-0359.2012v33n2p471

Barelli, M. A. A. (1997). Análise Dialélica da Capacidade Combinatória de Cultivares de Feijão (Phaseolus vulgaris L.) adaptados ao Noroeste Paranaense. Dissertação (Mestrado em Agronomia) - Universidade Estadual de Maringá - UEM - 1997.

Barelli, M. A. A., Vidigal, M. C. G., Amaral Júnior, A. T., Vidigal Filho, P. S., \& Scapim, C. A. (1998). Heterose relativa em feijoeiro (Phaseolus vulgaris L.). Acta Scientiarum, 20, 257-262. https://doi.org/10.4025/actasciagron.v20i0.4353.

Bitocchi, E., Bellucci, E., Giardini, A., Rau, D., Rodriguez, M., Biagetti, E., ... Roberto Papa, R. (2013). Molecular analysis of the parallel domestication of the common bean (Phaseolus vulgaris) in Mesoamerica and the Andes. New Phytologist. 197(1), 300-313. https://doi.org/10.1111/j.1469-8137.2012.04377.x

Ceyhan, E., Harmankaya, M., \& Kahraman, A. (2014). Combining ability and heterosis for concentration of mineral elements and protein in common bean (Phaseolus vulgaris L.). Turkish Journal of Agriculture and Forestry, 38, 581-590. https://doi.org/10.3906/tar-1307-56

Coelho, C. M. M., Coimbra, J. L. M., Souza, C. A., Bogo, A., \& Guidolin, A. F. (2007). Diversidade genética em acessos de feijão (Phaseolus vulgaris L.). Ciência Rural, 37(5), 1241-1247. https://doi.org/10.1590/S0103-84782007000500004

Correa, A. M., Lima, A. R. S., Braga, D. C., Ceccon, G., Teodoro, P. E., Silva Junior, C. A. da $\&$ Silva, F. A. (2015). Agronomic Performance and Genetic Variability among Common Bean Genotypes in Savanna/Pantanal Ecotone. Journal of Agronomy, 14(3), 175-179. https://doi.org/10.3923/ja.2015.175.179

Cruz, C. D. (2006) Programa GENES: biometria. Viçosa: Ed. UFV, 382p. 


\section{MlMacrothink}

Journal of Agricultural Studies

ISSN 2166-0379

2020, Vol. 8, No. 4

Cruz, C. D. (2013). GENES - a software package for analysis in experimental statistics and quantitative genetics. $\quad$ Acta Scientiarum, 35(3), 271-276. https://doi.org/10.4025/actasciagron.v35i3.21251

Dallacort, R., Neves, S. M. A. S., \& Nunes, M. C. M. (2014). Variabilidade da Temperatura e das Chuvas de Cáceres/Pantanal Mato-Grossense - Brasil. Geografia (Londrina), 23(1), 21-33. https://doi.org/10.5433/2447-1747.2014v23n1p21

Falconer, D. S. (1987). Introdução à genética quantitativa. Viçosa : UFV. 279p.

Faria, M. V., Morales, R. G. F., Resende, J. T. V., Zanin, D. S., Menezes, C. B., Kobori, R. F. (2012). Desempenho agronômico e heterose de genótipos de cebola. Horticultura Brasileira 30(2), 220-225. https://doi.org/10.1590/S0102-05362012000200007

Gardner, C. O., \& Eberhart, S. A. (1966) Analysis and interpretation of the variety cross diallel and related populations. Biometrics, 22, 439-452. https://doi.org/10.2307/2528181

Gerrano, A. S., Adebola, P. O., Rensburg, W. S. J. V., \& Laurie, S. M. (2015). Genetic variability in cowpea (Vigna unguiculata (L.) Walp.) genotypes. South African Journal of Plant and Soil, 32(3), 165-174. https://doi.org/10.1080/02571862.2015.1014435

Gonçalves, M. C. (1979) Correlações genotípicas, fenotípicas e de ambiente em feijoeiro (Phaseolus vulgaris L.). Tese (Mestrado) - Universidade Federal de Viçosa, Viçosa. 42p.

Gonçalves-Vidigal, M. C., Silvério, L., Elias, H. T., Vidigal Filho, P. S., Kvitschal, M. V., Retuci, V. S., \& Silva, C. R. da. (2008). Combining ability and heterosis in common bean $\begin{array}{llll}\text { cultivars. Pesquisa Agropecuária } \quad \text { Brasileira, 43(9), } & \text { 1143-1150. }\end{array}$ https://doi.org/10.1590/S0100-204X2008000900007

Griffing, J. B. (1956). Concept of general and specifc combinmg ability in relation to diallel systems. Australian Journal of Biological Science, 9, 463-493. Retrieved from https://doi.org/10.1071/BI9560463

Jinks, J. L., \& Hayman, B. I. (1953) The analysis of diallel crosses. Maize Genetics Corporation News Letter, 27, 48-54.

Kalavacharla, V., Liu, Z., Meyers, B. C., Thimmapuram, J., \& Melmaiee, K. (2011). Identification and analysis of common bean (Phaseolus vulgaris L.) transcriptomes by massively parallel pyrosequencing. BMC Plant Biology. 11(135). https://doi.org/10.1186/1471-2229-11-135

Krause, W., Rodrigues, R., \& Leal, N. R. (2012). Capacidade combinatória para características agronômicas em feijão-de-vagem. Revista Ciências Agrária. 43(3), 522-531. https://doi.org/10.1590/S1806-66902012000300015

Kurek, A. J., Carvalho, F. I. F., Assmann, I. C., \& Cruz, P. J. (2001). Capacidade combinatória como critério de eficiência na seleção de genitores de feijoeiro. Pesquisa agropecuária brasileira, 36(4), 645-651. https://doi.org/10.1590/S0100-204X2001000400007

Leite, P. H. M. P., Barelli, M. A. A., Neves, L. G., Silva, C. R., \& Oliveira, T. C. (2015) 
Genetic divergence among common bean cultivars from precocious group. Científica, 43(2), 143-148. https://doi.org/10.15361/1984-5529.2015v43n2p143-148

Leite, P. H. M. P., Silva, V. P., Gilio, T. A. S., Felipin-Azevedo, R., Oliveira, T. C., \& Barelli, M. A. A. (2019). Diversidade genética em cultivares e linhagens de feijão comum (Phaseolus vulgaris L.) utilizando análises multivariadas. Cultura Agronômica, 28(3), 268-279. https://doi.org/10.32929/2446-8355.2019v28n3p268-279

Oliveira, A. C., Silva, J, Santos, M. M., Cancellier, E. L., \& Fidelies, R. R. (2014). Desempenho agronômico de cultivares de feijão em função da adubação fosfatada no sul do Estado do Tocantins. Revista Caatinga, 27(1), 50-59. Retrieved from https://periodicos.ufersa.edu.br/index.php/caatinga/article/view/2657/pdf_85

Peternelli, L. A., \& Borém, A. (1999). Hibridação artificial em feijão. In: Borém, A. (Ed.). Hibridação artificial de plantas. Viçosa: Universidade Federal de Viçosa, p.269-294.

Pimentel Gomes, F. (1985). Curso de estatística experimental. São Paulo: Nobel, 467 p.

Rocha, F., Stinghen, J. C., Gemeli, M. S., Coimbra, J. L. M., \& Guidolin, A. F. (2014). Análise dialélica como ferramenta na seleção de genitores em feijão. Revista Ciência Agronômica. 45(1), 74-81. https://doi.org/10.1590/S1806-66902014000100010

Santos, A., Correa, A. M., Melo, C. L. P., Durante, L. G. Y., Carneiro, T., \& Oliveira, R. (2011). Desempenho agronômico de genótipos de feijão comum cultivados no período "da seca" em Aquidauana-MS. Revista Agrarian, 4(11), 3-42. Retrieved from http://ojs.ufgd.edu.br/index.php/agrarian/article/view/839/674

Senbetay, T., \& Tesfaye, A. (2015). Diallel analysis of white pea bean (Phaseolus vulgaris L.) varieties for yield and yield components. Journal of Biology, Agriculture and Healthcare, 5(5), 75-81. Retrieved from: file:///C:/Users/silva/Downloads/20629-23567-1-PB.pdf

Silva, A. B. (2013). Cruzamento dialélicos para caracteres agronômicos da cultura de feijão-de-vagem. Campos dos Goytacazes, Universidade do Norte Fluminense Darcy Ribeiro (Dissertação Mestrado em Genética e Melhoramento). 54p. Retrieved from http://uenf.br/posgraduacao/gmp/wp-content/uploads/sites/6/2013/07/Tese-MS-Andr\%C3\%A 9a-Barros-Silva.pdf

Silva, A. B. (2013). Cruzamento dialélicos para caracteres agronômicos da cultura de feijão-de-vagem. Campos dos Goytacazes, Universidade do Norte Fluminense Darcy Ribeiro (Dissertação Mestrado em Genética e Melhoramento). 54p.

Silva, V. M. P. e., Carneiro, P. C. S., Menezes Júnior, J. A. N. de, Carneiro, V. Q., Carneiro, J. E. S., Cruz, C. D., \& Borém, A. (2013). Genetic potential of common bean parents for plant architecture improvement. Scientia Agricola, 70(3), 167-175. https://doi.org/10.1590/S0103-90162013000300005

Stähelin, D., Valentini, G., Andrade, L.R. B., Verissimo, M. A. A., Bertoldo, J. G., Guidolin, A. F., \& Coimbra, J. L. M. (2011.) Screening multivariado entre acessos e cultivares de feijão do grupo preto para utilização em blocos de cruzamento. Biotemas, 24(1), 95-103. 
https://doi.org/10.5007/2175-7925.2011v24n1p95

Talukder, Z. I., Anderson, E., Miklas, P. N., Blair, M. W., Osorno, J., Dilawari, M., \& Hossain, G. (2010). Genetic diversity and selection of genotypes to enhance $\mathrm{Zn}$ and Fe content in common bean. Canadian Journal of Plant Science. 90(1), 49-60. https://doi.org/10.4141/CJPS09096

Tiruneh, M. A., Ali, H. M., \& Zelleke, H. (2013). Estimation of Better Parent and Economic Heterosis for Yield and Associated Traits in Common Beans. Journal of Applied Biosciences, 71, 5706-5714. https://doi.org/10.4314/jab.v71i1.98814

Torres, V. R., Domínguez, J. R. G., Barrios, A. B., Mendoza, A. B., \& Godina, F. R. (2002) Estudio de la heterosis em frijol común em condiciones de temporal. Revista de Fitotecnia Mexicana, 25, 65-70.

Tsutsumi, C. Y., Bulegon, L. G., \& Piano, J. T. (2015). Melhoramento genético do feijoeiro: avanços, perspectivas e novos estudos, no âmbito nacional. Nativa. 3(3), 217-223. https://doi.org/10.14583/2318-7670.v03n03a12

Vale, N. M., Barili, L. D., Oliveira, H. M., Carneiro, J. E. S., Carneiro, P. C. S., \& Silva, F. L. (2015). Escolha de genitores quanto à precocidade e produtividade de feijão tipo carioca. $\begin{array}{llll}\text { Pesquisa agropecuária } & \text { brasileira, } & \text { 141-148. }\end{array}$ https://doi.org/10.1590/S0100-204X2015000200006

Vidigal, M. C., Silvério, L., Elias, H. T., Filho, P. S., Kvitschal, M. V., Retuci, V. S., \& Silva C. R. (2008). Combining ability and heterosis in common bean cultivars. Pesquisa Agropecuária Brasileira. 43(9), 1143-1150.

https://doi.org/10.1590/S0100-204X2008000900007

Vieira, C. (1964). Curso de melhoramento de plantas. Viçosa: UFV. 245p.

Zimmermann, M. J. O., Carneiro, J. E. S., Del Peloso, M. J., Costa, J. G. C., Rava, C. A., Sartorato, O. A., \& Pereira, P. A. A. (1996). Melhoramento genético e cultivares. In: Araújo, RS, Rava, CA, Stone, LF, Zimmermann, MJO. (eds.) Cultura do feijoeiro comum no Brasil. Piracicaba: Potafos, p. 224-273.

\section{Copyright Disclaimer}

Copyright for this article is retained by the author(s), with first publication rights granted to the journal.

This is an open-access article distributed under the terms and conditions of the Creative Commons Attribution license (http://creativecommons.org/licenses/by/4.0/). 